\title{
The Coastal Tourism Climate Index (CTCI): Development, Validation, and Application for Chinese Coastal Cities
}

\author{
Caixia Gao ${ }^{1,2}$, Jiaming Liu ${ }^{1,2, *}$, Shuying Zhang ${ }^{3}$, He Zhu ${ }^{1}$ and Xin Zhang ${ }^{1,2}$ \\ 1 Key Laboratory of Regional Sustainable Development Modeling, Institute of Geographic Sciences and Natural \\ Resources Research, Chinese Academy of Sciences, Beijing 100101, China; gaocx.20b@igsnrr.ac.cn (C.G.); \\ zhuhe@igsnrr.ac.cn (H.Z.); zhangxin195@mails.ucas.ac.cn (X.Z.) \\ 2 College of Resources and Environment, University of Chinese Academy of Sciences, Beijing 100049, China \\ 3 State Key Laboratory of Resources and Environment Information System, Institute of Geographic Sciences and \\ Natural Resources Research, Chinese Academy of Sciences, Beijing 100101, China; zhangsy.17b@igsnrr.ac.cn \\ * Correspondence: liujm@igsnrr.ac.cn
}

check for updates

Citation: Gao, C.; Liu, J.; Zhang, S.; Zhu, H.; Zhang, X. The Coastal Tourism Climate Index (CTCI): Development, Validation, and Application for Chinese Coastal Cities. Sustainability 2022, 14, 1425. https://doi.org/10.3390/su14031425

Academic Editor: Andrea Zerboni

Received: 2 January 2022

Accepted: 24 January 2022

Published: 26 January 2022

Publisher's Note: MDPI stays neutral with regard to jurisdictional claims in published maps and institutional affiliations.

Copyright: (c) 2022 by the authors. Licensee MDPI, Basel, Switzerland. This article is an open access article distributed under the terms and conditions of the Creative Commons Attribution (CC BY) license (https:// creativecommons.org/licenses/by/ $4.0 /)$.

\begin{abstract}
Climate is an essential component in the sustainability of tourism cities. Coastal tourism cities face unprecedented challenges under a changing climate. The complexity of the tourism-climate interface predicates the need for tools that can assess the weather and climate accurately. Tourism climate indices have been widely developed to evaluate the temporal and spatial distribution of climate resources, but these indices are not entirely applicable to coastal cities facing air pollution. This study developed a Coastal Tourism Climate Index (CTCI) to assess the tourism climate suitability of Chinese coastal cities. The CTCI was developed to include five variables: thermal comfort, sunshine, precipitation, wind, and air quality. This index was applied and verified in the case of nine coastal tourism cities in China compared to the Holiday Climate Index (HCI: Beach). According to the results, the CTCI is more suitable for coastal tourism climate assessment in China. Finally, corresponding countermeasures are put forward for the balanced and sustainable development of Chinese coastal tourism cities. This study takes the lead in applying big data to the development and validation of tourism climate indices. These findings provide novel insights for the tourism climate assessment of coastal destinations facing air pollution.
\end{abstract}

Keywords: coastal cities; coastal tourism; Tourism Climate Index; climate change; air quality; big data; China

\section{Introduction}

Coastal tourism is one of the pillar industries of the marine economy in China, representing $50.6 \%$ of the added value of major marine industries in 2019 [1]. Thus, the sustainable development of coastal tourism in China is important. According to the national standard "Classification of Marine and Related Industries (GB/T 20794-2006)" in China, coastal tourism is defined as that including "those tourism business and service activities based on various natural and cultural landscapes in coastal zones, islands and oceans". Its concept embraces the full range of tourism, leisure, and recreationally oriented activities [2]. Hence, coastal tourism depends strongly on appropriate ecological circumstances and a sunny climate [3-5].

Climate is an essential component in the sustainability of coastal tourism cities [6]. Climate change has significant influences on tourist behaviors, tourism flows, and destination competitiveness [7-10]. Hence, assessing the tourism climate is necessary to aid in decision making, investment, operations, and planning [11,12]. The first attempt to present a quantitative evaluation of climate was the Tourism Climate Index (TCI) devised by Mieczkowski [13]. Over the past 30 years, a number of climate indices for coastal tourism have been developed for different destinations, such as the Beach Climate Index (BCI) [14], a second-generation climate index for tourism (CIT) [15], and the Holiday 
Climate Index (HCI) [16]. Tourism climate indices are effective tools to assess tourism climate conditions and can provide climate information for the sustainable development of coastal destinations.

However, these indices are not appropriate for the tourism climate assessment of Chinese coastal cities, because there is a lack of consideration of some emerging factors in China, such as air quality. In recent years, air pollution has had a significant adverse effect on the tourism cities in China [17]. For instance, haze weather has had impacts on tourist arrivals and destination preferences, because tourists carefully consider haze weather and shortlist their destinations based on these considerations [18]. This issue is most serious in several coastal provinces, including Hebei, Shandong, and Jiangsu [19]. In addition, air pollution in winter and spring is more serious than that in summer and autumn [20]. Thus, constructing a tourism climate index suitable for Chinese coastal cities is necessary to accurately assess the tourism climate suitability and avoid chaotic development against the background of climate change.

Accordingly, we propose a novel Coastal Tourism Climate Index (CTCI) for Chinese coastal cities. This paper includes the following objectives: (1) to develop a novel tourism climate index suitable for Chinese coastal cities; (2) to assess the tourism climate suitability accurately; and (3) to put forward sustainable development strategies for Chinese coastal cities. Based on the above objectives, this paper provides a contribution to enrich research content of tourism climate indices by developing a novel index (CTCI) including five climate variables: Temperature Humidity Index (THI), sunshine, precipitation, wind, and Air Quality Index (AQI). Two key methodological advancements of the CTCI include: (1) it uses the entropy method to improve the objectivity of the weightings of the subindices; and (2) it takes the lead in applying big data to the development and validation of a tourism climate index. Tourism climate indices are effective climate assessment tools that can translate climate conditions into coastal tourism decision-relevant information more comprehensively. This index can be transferable to global coastal destinations facing serious air pollution for climate assessment and provides the basis for marketing strategies and sustainable management measures. In conclusion, this study not only deepens research about tourism climate indices but also provides a reference for sustainable tourism policymaking in Chinese coastal cities.

\section{Literature Review}

The literature review explains climate, air quality and the development of coastal tourism, and gives an overview of previous research in tourism climatology.

\subsection{Climate, Air Quality, and Coastal Tourism Development}

Climate is a fundamental factor involved in various nature-based tourism activities [6]. Climate change has a significant influence on tourism resources, destination image, choice, tourism flows, and seasonality $[9,21,22]$. The term "weather" refers to short-term conditions (days to months), while "climate" refers to mid-term to long-term conditions (months to years) [23]. Tourists wish to know not only the long-term climate characteristics of an area, but also the probability and intensity of weather conditions for a month or even a day [16]. In addition, it is well documented that nature-based tourism across multiple activities, including beach tourism, ski tourism, camping, and park visitation, requires different climatic conditions [24-27]. Traditionally, coastal tourism activities have been based on beaches and seawater. Hence, temperature, relative humidity, sunshine hours, wind, and cloud cover are often considered the main climate variables that influence beach tourism demand [28]. Nowadays, coastal cities are emerging as powerhouses of tourism interest [29]. As a result, the weather conditions required for coastal tourism activities have become more complex in recent years.

Climate change and its potential consequences are becoming more important than ever before [30]. One important aspect of climate change is variations in air quality [31]. With global climate change, air quality is significantly influencing the attractiveness and 
tourism demand of various cities [32]. Intuitively, air pollution inhibits the development of the tourism industry. Tourists refrain from sightseeing in cities where air quality causes health concerns [33]. Scholars generally agree that poorer air quality may decrease the tourism demand and the competitiveness of a tourism destination, and the negative effect is more pronounced for international tourism than for domestic tourism [34-37]. In general, prior literature shows that China is a major focus of these types of studies, and visitors from China usually highly value pure air and the natural environment [38]. However, air quality has not been referred to in previous studies on tourism climate assessment. Thus, it is necessary to comprehensively assess the climate for Chinese coastal tourism cities in the context of air pollution.

\subsection{Tourism Climate Indices for Coastal Destinations}

Tourism Climate Indices (TCIs) have been widely discussed as tools for evaluating climatic suitability since Mieczkowski developed the Tourism Climate Index (TCI) [13]. This index was established to evaluate world climates for general sightseeing and not for specific tourism segments. Over the past 30 years, indices designed for coastal tourism have emerged subsequent to the TCI, including the Beach Climate Index (BCI), a secondgeneration Climate Index for Tourism (CIT), the Modified Climate Index for Tourism (MCIT), the Optimized Index (OPT), and the Holiday Climate Index: Beach (HCI: Beach), among others $[14,15,39-41]$. These works have contributed to substantial progress in the study of tourism climatology. However, there are some critical limitations in the previous literature, including the subjectivity of climate resource weights and ratings, insufficient empirical testing for indices using observed tourist behaviors, and the inability to recognize the effects of extreme events [23].

Most studies have focused their attention on coastal destinations in Europe, the Mediterranean, Australia, the United States, and Canada, while Chinese coastal destinations have been scarcely explored [42,43]. These indices are not suitable for the tourism assessment of Chinese coastal cities due to the lack consideration of air quality. For example, the $\mathrm{BCI}$ encompasses five weighted sub-indices: thermal sensation, precipitation, sunshine, wind, and bathing water temperature. The HCI and OPT contain four weighted facets: thermal comfort, aesthetic, precipitation, and wind [44]. Moreover, these evaluation models all adopt weighted summation in form, but the methods for improving the objectivity of the index weight are still worth in-depth discussion. In particular, a number of studies have suggested that the weight for each component varies among different countries [45-47].

In terms of empirical validation data of these indices, visitation numbers, occupancy rates, and tourist climate preferences have been used as indicators of weather conditions that affect tourism demand $[15,40,48]$. However, these structured data can be insufficient due to the small sample size. Compared with the traditional structured data, big data such as social media data and Internet search engine data are most widely incorporated into tourism research nowadays [49]. Previous studies have demonstrated that tourists use search engines to obtain weather and destination information [50]. Hence, the tourist flow and social behavior can be predicted from the massive volume of search data available on the Internet [51,52]. Internet data, especially from Google and Baidu, are attracting increasing attention from scholars in the field of tourism [53-56]. Baidu search data have been used widely in the forecasting of tourist arrivals and hotels in China [57,58]. Hence, using Baidu search data as validation data can be an important method to improve the accuracy of climate assessment models. 


\section{Materials and Methods}

The materials and methods will introduce the Chinese coastal cities, data sources and analysis methods for the development of the CTCI.

\subsection{Study Area}

Nine coastal tourism cities in China, from north to south, were chosen for this study, including Dalian, Qinhuangdao, Qingdao, Nantong, Shanghai, Hangzhou, Fuzhou, Xiamen, and Haikou (see Figure 1). These cities are major tourist destinations in China and have experienced rapid economic growth within the tourism industry. According to the Yearbook of China Tourism Statistics, in 2017, the nine coastal tourism cities received 15,319,201 tourists, accounting for 34 percent of the total number of major coastal tourism cities in China, and the tourists' average stay in one of these coastal cities is approximately four days. These cities are appealing to tourists due to their ideal climate, coastal and marine scenery, resorts, suitability as locations for second homes, and variety of entertainment (e.g., sightseeing, beach recreational activities, sports, cruises, and diving). Moreover, these cities also span the country's three major climatic zones, namely temperate regions, subtropical regions, and tropical regions. Therefore, these cases cannot only allow us to better explain the spatial and temporal differences in the coastal tourism climate in China, but also expand the application scope of the CTCI.

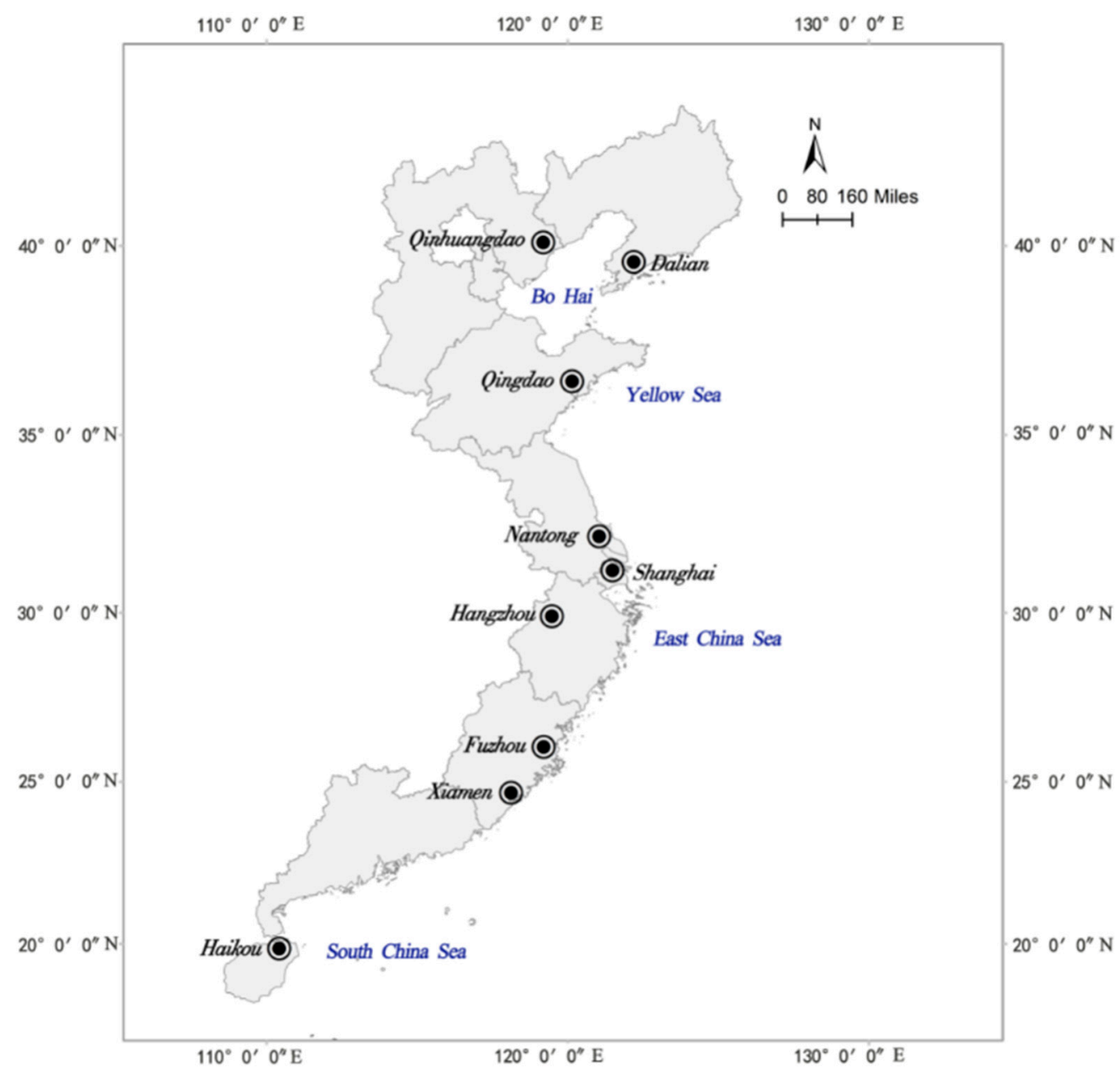

Figure 1. Location map of nine coastal tourism cities in China included in this study. 


\subsection{Data Sources}

\subsubsection{Climate Data}

The climate data (temperature, relative humidity, wind speed, precipitation, and sunshine hours) were derived from the "China Surface Climate Data Monthly Data Set" provided by the National Meteorological Information Center (China Meteorological Data Network, http:/ / data.cma.cn/, accessed on 5 March 2021). The monthly data of the nine coastal cities from 1 January 2013, to 31 December 2020, were obtained.

\subsubsection{Air Quality Index}

The data of the Air Quality Index (AQI) were derived from the Monthly Report of Urban Air Quality (between 1 January 2013 and 31 December 2020) provided on the official website of the Ministry of Ecology and Environment of the People's Republic of China (https: / / www.mee.gov.cn/, accessed on 8 March 2021). The AQI is a dimensionless index that describes the comprehensive situation of urban ambient air quality and has been reported since January 2013. It combines the concentration values of six pollutants, namely $\mathrm{SO}_{2}, \mathrm{NO}_{2}, \mathrm{PM} 10, \mathrm{PM} 2.5, \mathrm{CO}$, and $\mathrm{O}_{3}$. The higher the AQI, the more polluted the air. We used the average values of AQI in November 2013 and November 2015 to supplement the missing values of AQI in November 2014 for the nine cities. Due to the changing amplitude of the AQI, the values in three adjacent years are the smallest. In order to maintain the consistency of the temporal granularity of climate data, we used monthly data for calculation. The AQI is higher in winter, lower in summer, and moderate in spring and autumn. The mean value of the AQI in northern cities is higher than that in southern cities.

\subsubsection{Baidu Index}

The Baidu Index is a free online search application with massive amounts of data (https: / /index.baidu.com/v2/index.html\#/, accessed on 15 March 2021), and it is used to calculate the frequency of different keywords in different periods of time, reflecting the different keywords "user awareness" and "media attention" during a given period. In order to identify tourism-related searching behaviors, we selected "Dalian + tourism", "Qinhuangdao + tourism", "Qingdao + tourism", "Nantong + tourism", "Shanghai + tourism", "Hangzhou + tourism", "Fuzhou + tourism", "Xiamen + tourism", and "Haikou + tourism" as base keywords (between 1 January 2013 and 31 December 2020), and then searched for these keywords through the Baidu Index to determine the frequency of mentions. Baidu search trend data are absolute values and vary among different cities and seasons, with obvious regional differences and seasonal characteristics.

\subsection{Analysis Methods}

The development of the CTCI included three steps: (1) assess the weightings of the sub-indices using the information entropy weight method (IEW); (2) determine the weather variable rating scores and thresholds based on the Chinese meteorological standard and related literature; and (3) empirically validate the index using the Baidu Index for coastal tourism cities in China.

For a tourism climate index, the weightings of the sub-indices are crucial to measure the index's importance. In this paper, we used SPSS software to calculate the weightings, named the Information Entropy Weight (IEW), based on the information entropy and the practical background of weather data. The entropy method is an objective weighting method. This method is commonly used in statistics and other fields [59,60]. The weightings of the sub-indices are identified according to the influence of the relative change degree of the sub-indices on the overall system. The larger the relative change in the sub-indices, the larger the weighting. 


\section{Results and Discussion}

In the following, the results and discussion section will outline the development and validation of the CTCI. The results will present climatic trends and suitability across the Chinese major coastal tourism cities using the CTCI.

\subsection{The CTCI Formula}

When these five variables are identified in accordance with the Baidu Index, the CTCI formula is expressed as:

$$
\mathrm{CTCI}=\beta 1 \cdot \mathrm{THI}+\beta 2 \cdot \mathrm{S}+\beta 3 \cdot \mathrm{P}+\beta 4 \cdot \mathrm{W}+\beta 5 \cdot \mathrm{A}
$$

where THI (monthly temperature humidity index) represents the thermal comfort resources; $\mathrm{S}$ (monthly average daily bright sunshine hours, $\mathrm{h}$ ) represents the aesthetic resources; $\mathrm{P}$ (monthly average daily precipitation, $\mathrm{mm}$ ), W (monthly maximum wind speed, $\mathrm{km} / \mathrm{h}$ ), and $\mathrm{A}$ (monthly air quality index) represent the physical resources. $\beta n(n=1,2,3,4,5)$ represents the weight value of each variable.

Next, we used the Information Entropy Weight method (IEW) to assess the weightings of these sub-indices. After dimensional processing of the variable data, the results were calculated as follows (see Table 1).

Table 1. The weightings of sub-indices.

\begin{tabular}{cccccc}
\hline Variables & THI & Sunshine & Precipitation & AQI & Wind \\
\hline Weight coefficient & $33.1 \%$ & $46.8 \%$ & $7.7 \%$ & $9.9 \%$ & $2.5 \%$ \\
\hline
\end{tabular}

Finally, the CTCI formula was defined as:

$$
\mathrm{CTCI}=0.331 \cdot \mathrm{THI}+0.468 \cdot \mathrm{S}+0.077 \cdot \mathrm{P}+0.025 \cdot \mathrm{W}+0.099 \cdot \mathrm{A}
$$

Each of the five sub-indices has a score of 0 to 10, as does the final CTCI score.

\subsection{Variable Thresholds and Rating Scores}

Previous studies show that both the BCI index and the OPT index are suitable for small-scale regional climate assessment, whereas the TCI and HCI: Beach are applicable to larger-scale areas. Moreover, variable thresholds vary among different countries. Hence, in this study, the threshold values and sub-index scores of the CTCI were determined based on the TCI, HCI: Beach, Chinese meteorological standard, and related literature. Each climatic variable in the CTCI is rated on a scale from 0 to 10 , with an overall CTCI index score of 0 to 100.

\subsubsection{THI Facet}

As shown in Table 2, the CTCI identified 21 different thermal comfort ranges and assigned sub-index scores between 0 and 10. The CTCI assigns a score of 10 when THI is between 24.0 and 24.9. For the lowest rating of the THI, the CTCI assigns a score of 0 for days with $\mathrm{THI} \geq 28.0$ and $\mathrm{THI}<15.0$, because this weather condition is no longer suitable for coastal tourism in China, as indicated by Fan and Guo [61]. CTCI ratings reflect the higher thermal tolerance of coastal and beach tourists, consistent with the HCI: Beach. 
Table 2. THI facet rating schemes.

\begin{tabular}{|c|c|c|c|c|c|}
\hline \multicolumn{2}{|c|}{ HCI: Beach } & \multicolumn{2}{|c|}{$\begin{array}{l}\text { Climate Suitability Assessment } \\
\text { for Coastal Tourism in China }\end{array}$} & \multicolumn{2}{|c|}{ CTCI } \\
\hline THumidex $\left({ }^{\circ} \mathrm{C}\right)$ & Rating & THI & Feeling Degree & THI & Rating \\
\hline$\geq 39.0$ & 0 & \multirow{8}{*}{$>28.0$} & \multirow{8}{*}{ torrid } & & \\
\hline $38.0 \sim 38.9$ & 2 & & & & \\
\hline $37.0 \sim 37.9$ & 4 & & & $\geq 28.0$ & 0 \\
\hline $36.0 \sim 36.9$ & 5 & & & & \\
\hline $35.0 \sim 35.9$ & 6 & & & & \\
\hline $34.0 \sim 34.9$ & 7 & & & $27.5 \sim 27.9$ & 3 \\
\hline $33.0 \sim 33.9$ & 8 & & & $27.0 \sim 27.4$ & 5 \\
\hline $31.0 \sim 32.9$ & 9 & & & $26.5 \sim 26.9$ & 6 \\
\hline $28.0 \sim 30.9$ & 10 & \multirow{2}{*}{$27.0 \sim 28.0$} & \multirow{2}{*}{ hot } & $26.0 \sim 26.4$ & 7 \\
\hline $26.0 \sim 27.9$ & 9 & & & $25.5 \sim 25.9$ & 8 \\
\hline $23.0 \sim 25.9$ & 7 & \multirow[t]{2}{*}{$25.0 \sim 26.9$} & \multirow[t]{2}{*}{ warm * } & $25.0 \sim 25.4$ & 9 \\
\hline $22.0 \sim 22.9$ & 6 & & & & \\
\hline $21.0 \sim 21.9$ & 5 & \multirow{2}{*}{$17.0 \sim 24.9$} & \multirow[t]{2}{*}{ comfort $* *$} & \multirow[t]{2}{*}{$24.0 \sim 24.9$} & \multirow[t]{2}{*}{10} \\
\hline $20.0 \sim 20.9$ & 4 & & & & \\
\hline $19.0 \sim 19.9$ & 3 & \multirow[t]{4}{*}{$15.0 \sim 16.9$} & \multirow[t]{6}{*}{$\mathrm{cool}^{*}$} & $23.0 \sim 23.9$ & 9 \\
\hline $18.0 \sim 18.9$ & 2 & & & $22.0 \sim 22.9$ & 8 \\
\hline $17.0 \sim 17.9$ & 1 & & & $21.0 \sim 21.9$ & 7 \\
\hline $15.0 \sim 16.9$ & 0 & & & $20.0 \sim 20.9$ & 6 \\
\hline $10.0 \sim 14.9$ & -5 & \multirow{2}{*}{$<15.0$} & & $19.0 \sim 19.9$ & 5 \\
\hline & & & & $18.0 \sim 18.9$ & 4 \\
\hline \multirow{4}{*}{$\leq 9.9$} & \multirow{4}{*}{-10} & & \multirow{4}{*}{ cold } & $17.0 \sim 17.9$ & 3 \\
\hline & & & & $16.0 \sim 16.9$ & 2 \\
\hline & & & & $15.0 \sim 15.9$ & 1 \\
\hline & & & & $<15.0$ & 0 \\
\hline
\end{tabular}

Note: ${ }^{*}$ suitable for sightseeing; ${ }^{* *}$ suitable for sightseeing and vacation [61].

\subsubsection{Sunshine Facet}

The TCI uses mean monthly hours of sunshine per day for the aesthetic facet, whereas the HCI: Beach uses the percentage of cloud cover instead of sunshine hours because of the lack of meteorological data. However, sunshine conditions are still usually regarded as a necessary and significant factor for coastal tourism and beach recreation. Accordingly, we selected sunshine data to develop the CTCI index to be consistent with the original TCI (see Table 3). The CTCI gives the highest score of 10 when there are more than $10 \mathrm{~h}$ of sunshine, and rating scores become lower with a decrease in sunshine hours.

Table 3. Sunshine facet rating schemes.

\begin{tabular}{|c|c|c|c|c|c|}
\hline \multicolumn{2}{|l|}{ TCI } & \multicolumn{2}{|c|}{ HCI: Beach } & \multicolumn{2}{|c|}{ CTCI } \\
\hline Sunshine Hours & Rating & Cloud Cover (\%) & Rating & Sunshine Hours & Rating \\
\hline$<1 \mathrm{~h}$ & 0.0 & $0.0-0.9$ & 8 & $<1 \mathrm{~h}$ & 0 \\
\hline $1 \mathrm{~h} \sim 1 \mathrm{~h} 59 \mathrm{~min}$ & 0.5 & $1.0-14.9$ & 9 & $1 \mathrm{~h} \sim 1 \mathrm{~h} 59 \mathrm{~min}$ & 1 \\
\hline $2 \mathrm{~h} \sim 2 \mathrm{~h} 59 \mathrm{~min}$ & 1.0 & $15.0-25.9$ & 10 & $2 \mathrm{~h} \sim 2 \mathrm{~h} 59 \mathrm{~min}$ & 2 \\
\hline $3 \mathrm{~h} \sim 3 \mathrm{~h} 59 \mathrm{~min}$ & 1.5 & $26.0-35.9$ & 9 & $3 \mathrm{~h} \sim 3 \mathrm{~h} 59 \mathrm{~min}$ & 3 \\
\hline $4 \mathrm{~h} \sim 4 \mathrm{~h} 59 \mathrm{~min}$ & 2.0 & $36.0-45.9$ & 8 & $4 \mathrm{~h} \sim 4 \mathrm{~h} 59 \mathrm{~min}$ & 4 \\
\hline $5 \mathrm{~h} \sim 5 \mathrm{~h} 59 \mathrm{~min}$ & 2.5 & $46.0-55.9$ & 7 & $5 \mathrm{~h} \sim 5 \mathrm{~h} 59 \mathrm{~min}$ & 5 \\
\hline $6 \mathrm{~h} \sim 6 \mathrm{~h} 59 \mathrm{~min}$ & 3.0 & $56.0-65.9$ & 6 & $6 \mathrm{~h} \sim 6 \mathrm{~h} 59 \mathrm{~min}$ & 6 \\
\hline $7 \mathrm{~h} \sim 7 \mathrm{~h} 59 \mathrm{~min}$ & 3.5 & $66.0-75.9$ & 5 & $7 \mathrm{~h} \sim 7 \mathrm{~h} 59 \mathrm{~min}$ & 7 \\
\hline $8 \mathrm{~h} \sim 8 \mathrm{~h} 59 \mathrm{~min}$ & 4.0 & $76.0-85.9$ & 4 & $8 \mathrm{~h} \sim 8 \mathrm{~h} 59 \mathrm{~min}$ & 8 \\
\hline $9 \mathrm{~h} \sim 9 \mathrm{~h} 59 \mathrm{~min}$ & 4.5 & $86.0-95.9$ & 3 & $9 \mathrm{~h} \sim 9 \mathrm{~h} 59 \mathrm{~min}$ & 9 \\
\hline$\geq 10 \mathrm{~h}$ & 5.0 & $\geq 96.0$ & 2 & $\geq 10 \mathrm{~h}$ & 10 \\
\hline
\end{tabular}




\subsubsection{Precipitation Facet}

The CTCI identified 11 different precipitation ranges, which was consistent with HCI: Beach. However, when further dividing the rainfall thresholds, we used the national standard of the grade of precipitation in China (see Table 4). Depending on the PRC national standard "Short-range weather forecast" (GB/T 21984-2017), the grade of precipitation (within $24 \mathrm{~h}$ ) in China has 11 categories. The CTCI assigns a score of 10 for precipitation $(\mathrm{mm})=0 \mathrm{~mm}$, corresponding to the grading of HCI: Beach. Then, the grade of light rain (precipitation between 0.1 and $9.9 \mathrm{~mm}$ ) was identified as nine ranges with scores of 9 1. For the lowest rating of the precipitation facet, the CTCI assigns a score of 0 to precipitation $\geq 10.00$, when the grade of precipitation is described as "moderate rain". These ratings are more reflective of the tolerance for precipitation among leisure tourists on a coastal vacation in China.

Table 4. Precipitation facet rating schemes.

\begin{tabular}{|c|c|c|c|c|c|}
\hline \multicolumn{2}{|c|}{ HCI: Beach } & \multicolumn{2}{|c|}{$\begin{array}{l}\text { National Standard of the Grade of } \\
\text { Precipitation in China } \\
\text { (GB/T 21984-2017) }\end{array}$} & \multicolumn{2}{|c|}{ CTCI } \\
\hline $\begin{array}{l}\text { Precipitation } \\
\text { (mm) }\end{array}$ & Rating & $\begin{array}{l}\text { Precipitation } \\
(\mathrm{mm})\end{array}$ & Grade & $\begin{array}{l}\text { Precipitation } \\
(\mathrm{mm})\end{array}$ & Rating \\
\hline 0 & 10 & $<0.1$ & scattered rain & 0 & 10 \\
\hline $0.01 \sim 2.99$ & 9 & $0.1 \sim 9.9$ & light rain & $0.1 \sim 1.9$ & 9 \\
\hline $3.00 \sim 5.99$ & 8 & $10.0 \sim 24.9$ & moderate rain & $2.0 \sim 2.9$ & 8 \\
\hline $6.00 \sim 8.99$ & 6 & $25.0 \sim 49.9$ & heavy rain & $3.0 \sim 3.9$ & 7 \\
\hline $9.00 \sim 11.99$ & 4 & $50.0 \sim 99.9$ & intense fall & $4.0 \sim 4.9$ & 6 \\
\hline \multirow[t]{3}{*}{$12.00 \sim 24.99$} & 0 & $100.0 \sim 249.9$ & cloudburst & $5.0 \sim 5.9$ & 5 \\
\hline & & & & $6.0 \sim 6.9$ & 4 \\
\hline & & & & $7.0 \sim 7.9$ & 3 \\
\hline \multirow{3}{*}{$\geq 25.00$} & -1 & $\geq 250.0$ & extraordinary & $8.0 \sim 8.9$ & 2 \\
\hline & & & rainstorm & $9.0 \sim 9.9$ & 1 \\
\hline & & & & $\geq 10$ & 0 \\
\hline
\end{tabular}

\subsubsection{Wind Facet}

For wind, the HCI: Beach has eight categories and scores the highest when the wind speed is in the range of $0.6 \sim 9.9 \mathrm{~km} / \mathrm{h}$ (see Table 5). Based on the HCI: Beach and the Beaufort scale (GB/T 21984-2017), the CTCI assigns the highest score of 10 for days with wind speeds of $6.0 \sim 11.9 \mathrm{~km} / \mathrm{h}$. In this situation, tourists feel most comfortable in coastal destinations. When the wind speed is in the range of $1.0 \sim 5.9 \mathrm{~km} / \mathrm{h}$, the CTCI assigns a score of 9 , because this is also relatively suitable for coastal tourism. As the wind speeds increase above $11.9 \mathrm{~km} / \mathrm{h}$, the score decreases. The lowest score of 0 occurs when the grade of wind is described as "hurricane" with the wind speed $\geq 56 \mathrm{~km} / \mathrm{h}$ (dangerous for coastal tourism activities).

Table 5. Wind facet rating schemes.

\begin{tabular}{cccccc}
\hline HCI: Beach & \multicolumn{2}{c}{$\begin{array}{c}\text { Beaufort Scale } \\
\text { (GB/T 21984-2017) }\end{array}$} & CTCI \\
\hline Wind (km/h) & Rating & Wind (km/h) & Grade & Wind (km/h) & Rating \\
\hline $0 \sim 0.5$ & 8 & $<1$ & calm & $<1.0$ & 8 \\
$0.6 \sim 9.9$ & 10 & $1 \sim 5$ & light air & $1.0 \sim 5.9$ & 9 \\
$10.0 \sim 19.9$ & 9 & $6 \sim 11$ & light breeze & $6.0 \sim 11.9$ & 10 \\
$20.0 \sim 29.9$ & 8 & $12 \sim 19$ & gentle breeze & $12.0 \sim 15.9$ & 9 \\
$30.0 \sim 39.9$ & 6 & $20 \sim 28$ & moderate breeze & $16.0 \sim 19.9$ & 8 \\
$40.0 \sim 49.9$ & 3 & $29 \sim 38$ & fresh breeze & $20.0 \sim 24.9$ & 7 \\
$50.0 \sim 69.9$ & 0 & $39 \sim 49$ & strong breeze & $25.0 \sim 28.9$ & 6 \\
& & $50 \sim 61$ & moderate gale & $29.0 \sim 33.9$ & 5 \\
$\geq 70.0$ & & $62 \sim 74$ & fresh gale & $34.0 \sim 38.9$ & 4 \\
& -10 & $75 \sim 88$ & strong gale & $39.0 \sim 43.9$ & 3 \\
& & $89 \sim 102$ & whole gale & $44.0 \sim 49.9$ & 2 \\
\end{tabular}




\subsubsection{AQI Facet}

The Air Quality Index (AQI) is a dimensionless index describing the comprehensive status of urban ambient air quality. It comprehensively considers the pollution levels of six pollutants, namely $\mathrm{SO}_{2}, \mathrm{NO}_{2}, \mathrm{PM} 10, \mathrm{PM} 2.5, \mathrm{CO}$, and $\mathrm{O}_{3}$. The larger the composite index value, the heavier the degree of pollution. According to the National Urban Air Quality Report in December 2020, Xiamen (AQI = 2.56), Lhasa (AQI = 2.83), Beijing (AQI = 3.55), Shenzhen $(\mathrm{AQI}=3.69)$, Dalian $(\mathrm{AQI}=3.81)$, and Wenzhou (AQI = 3.86) were evaluated as having "good air quality", and the air quality level of other cities gradually decreased. Thus, air quality rating schemes are as follows (see Table 6). The highest rating (10) is given to AQI in the range of $0.0 \sim 1.9$. The lower scores of $9 \sim 8$ are given to days with AQI in the range of 2.0 3.9. For the lowest rating of the air quality facet, the CTCI assigns a score of 0 to $\mathrm{AQI} \geq 11$.

Table 6. AQI rating schemes.

\begin{tabular}{ccc}
\hline & CTCI & \\
\hline AQI & Rating \\
\hline $0.0 \sim 1.9$ & 10 \\
$2.0 \sim 2.9$ & 9 \\
$3.0 \sim 3.9$ & 8 \\
$4.0 \sim 4.9$ & 7 \\
$5.0 \sim 5.9$ & 6 \\
$6.0 \sim 6.9$ & 5 \\
$7.0 \sim 7.9$ & 4 \\
$8.0 \sim 8.9$ & 3 \\
$9.0 \sim 9.9$ & 2 \\
$10.0 \sim 10.9$ & 1 \\
$\geq 11$ & 0 \\
\hline
\end{tabular}

\subsubsection{Rating Systems for CTCI}

Corresponding with the detailed descriptive categories of the HCI: Beach, this article proposes a simplified rating system (ideal, acceptable, unfavorable) based on Chinese tourist travel behavior (see Table 7). CTCI scores of 6.0 10.0 were deemed ideal for most of the tourists, and these five facets are all within the range of good conditions, indicating suitability for both sightseeing and vacations. Acceptable categories signify that this combination of weather conditions is suitable for sightseeing but not vacations in China. CTCI scores of 0.0 4.9 were deemed unfavorable for most tourists.

Table 7. Rating systems of the Holiday Climate Index (HCI: Beach) and Coastal Climate Index (CTCI).

\begin{tabular}{|c|c|c|c|}
\hline \multicolumn{2}{|c|}{ HCI: Beach } & \multicolumn{2}{|c|}{ CTCI } \\
\hline Score & Descriptive Rating & Score & Descriptive Rating \\
\hline $9.0 \sim 10.0$ & ideal & & \\
\hline $8.0 \sim 8.9$ & excellent & & \\
\hline $7.0 \sim 7.9$ & very good & $6.0 \sim 10.0$ & ideal \\
\hline $6.0 \sim 6.9$ & good & & \\
\hline $5.0 \sim 5.9$ & acceptable & $5.0 \sim 5.9$ & acceptable \\
\hline $3.0 \sim 4.9$ & marginal & & \\
\hline $1.0 \sim 2.9$ & unacceptable & $0.0 \sim 4.9$ & unfavorable \\
\hline $0.0 \sim 0.9$ & dangerous & & \\
\hline
\end{tabular}




\subsection{Validation and Results}

\subsubsection{Validating the CTCI}

The CTCI was validated by comparing it to the HCI: Beach. First, scores for the CTCI and HCI: Beach were calculated (from 1 January 2013 and 31 December 2020); then, they were averaged monthly to facilitate comparisons. Second, we used the R-squared $\left(R^{2}\right)$ coefficient (linear regression model) to test the relative strength of the relationship between the climate index score and Baidu Index. $\mathrm{R}^{2}$ values are between 0.0 and 1.0. The closer the return value is to 1.0 , the better the model is.

As shown in Table 8, the CTCI demonstrated a stronger fit than the HCI: Beach for $78 \%$ (7/9) of the observations. All cities have higher $\mathrm{R}^{2}$ values between CTCI and Baidu Index except Fuzhou and Xiamen. Stronger correlations are noted for both indices and Baidu Index to Dalian, Qinhuangdao, Qingdao and Nantong (all $R^{2}$ values $\geq 0.6$ ). The four seasons are distinct in these Chinese northern cities. Lower $R^{2}$ values are shown between HCI: Beach and Baidu Index in southern cities (Hangzhou, Fuzhou, Xiamen, and Haikou). The results show that CTCI can assess the climate of Chinese coastal tourism cities more accurately. In addition, the research methods used in this study are also effective for the construction of a tourism climate assessment model.

Table 8. $\mathrm{R}^{2}$ values between the climate index score and the Baidu Index (from January 2013 to November 2020).

\begin{tabular}{cccccccccc}
\hline $\mathbf{R}^{\mathbf{2}}$ & Dalian & Qinhuangdao & Qingdao & Nantong & Shanghai & Hangzhou & Fuzhou & Xiamen & Haikou \\
\hline CTCI & 0.71 & 0.84 & 0.71 & 0.69 & 0.44 & 0.60 & 0.36 & 0.20 & 0.64 \\
HCI: Beach & 0.74 & 0.64 & 0.61 & 0.68 & 0.60 & 0.48 & 0.10 & 0.11 & 0.05 \\
\hline
\end{tabular}

\subsubsection{Tourism Climate Assessment of Chinese Coastal Cities}

Regional differences exist in terms of the overall suitability for coastal tourism. Haikou has higher yearly average CTCI, while other cities have relative lower CTCI except for few peak seasons. As can be observed in Figures 2 and 3, the CTCI can better express the spatial and temporal changes in the suitability of the coastal tourism climate in China. First, the $\mathrm{CTCI}$ and $\mathrm{HCI}$ display strong consistency in the tourism climate assessment of Chinese coastal cities located in the temperate zone. Dalian, Qinhuangdao, and Qingdao are cold in winter and comfortable in summer, a trend that coastal tourism activities followed. The meteorological conditions are comparable. However, the CTCI scores are lower than the HCI: Beach scores from November to January since these months are usually the most polluted in Northern China. Second, the CTCI demonstrates better performance than HCI: Beach in the climate assessment of subtropical and tropical coastal cities. Figure 2 shows that the HCI scores are much higher than the CTCI scores throughout the year. In fact, these coastal cities (Nantong, Shanghai, Hangzhou, Fuzhou, Xiamen, and Haikou) have the most comfortable climate only in spring and autumn due to the great influence of tropical cyclones and cold waves (see Figure 3). 

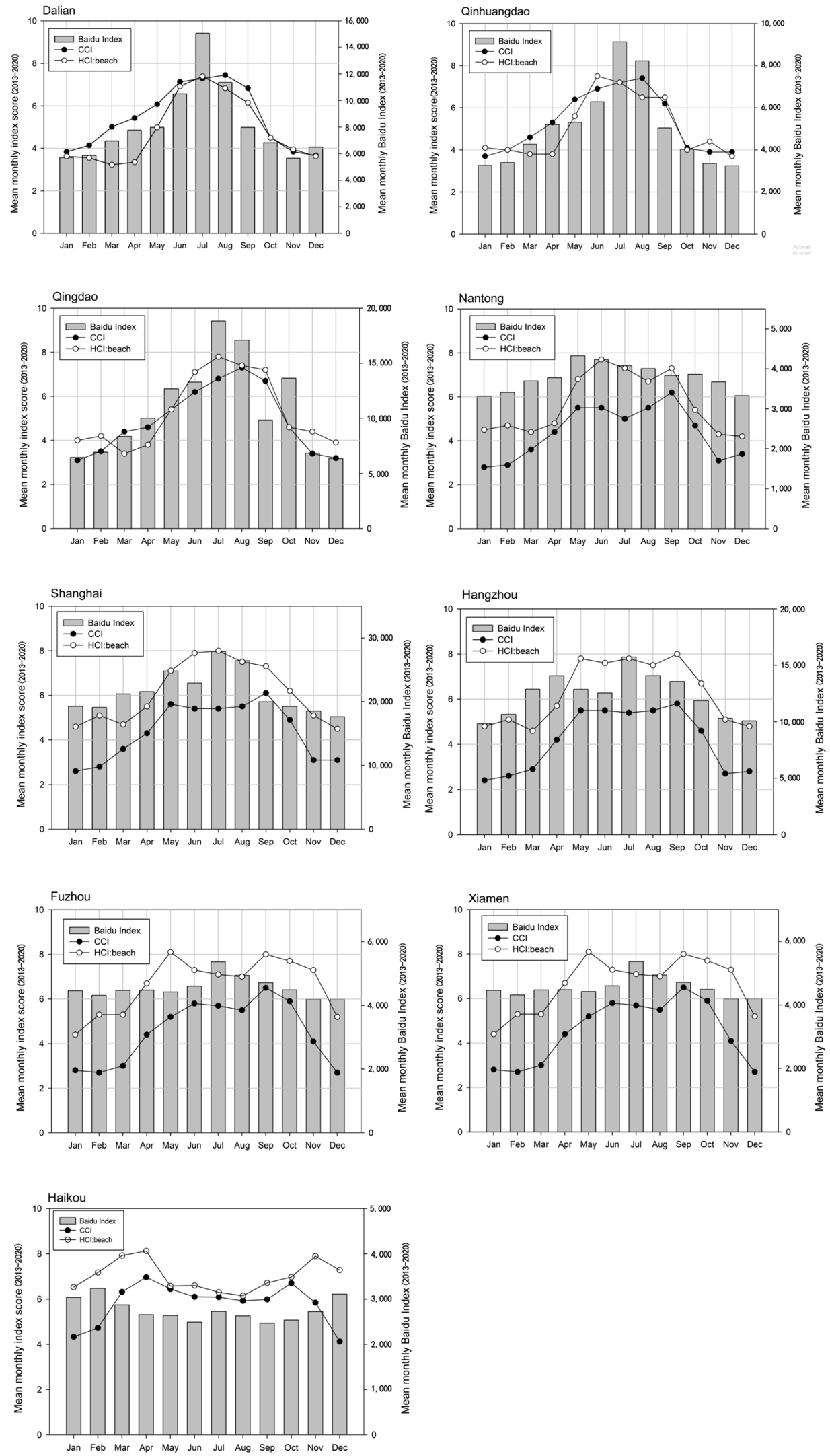

Figure 2. Validation of the CTCI and HCI: Beach with the Baidu Index. (Note: The lines and scatter represent the monthly averaged CTCI score and HCI: Beach score. The vertical bar is the monthly averaged Baidu Index score.). 


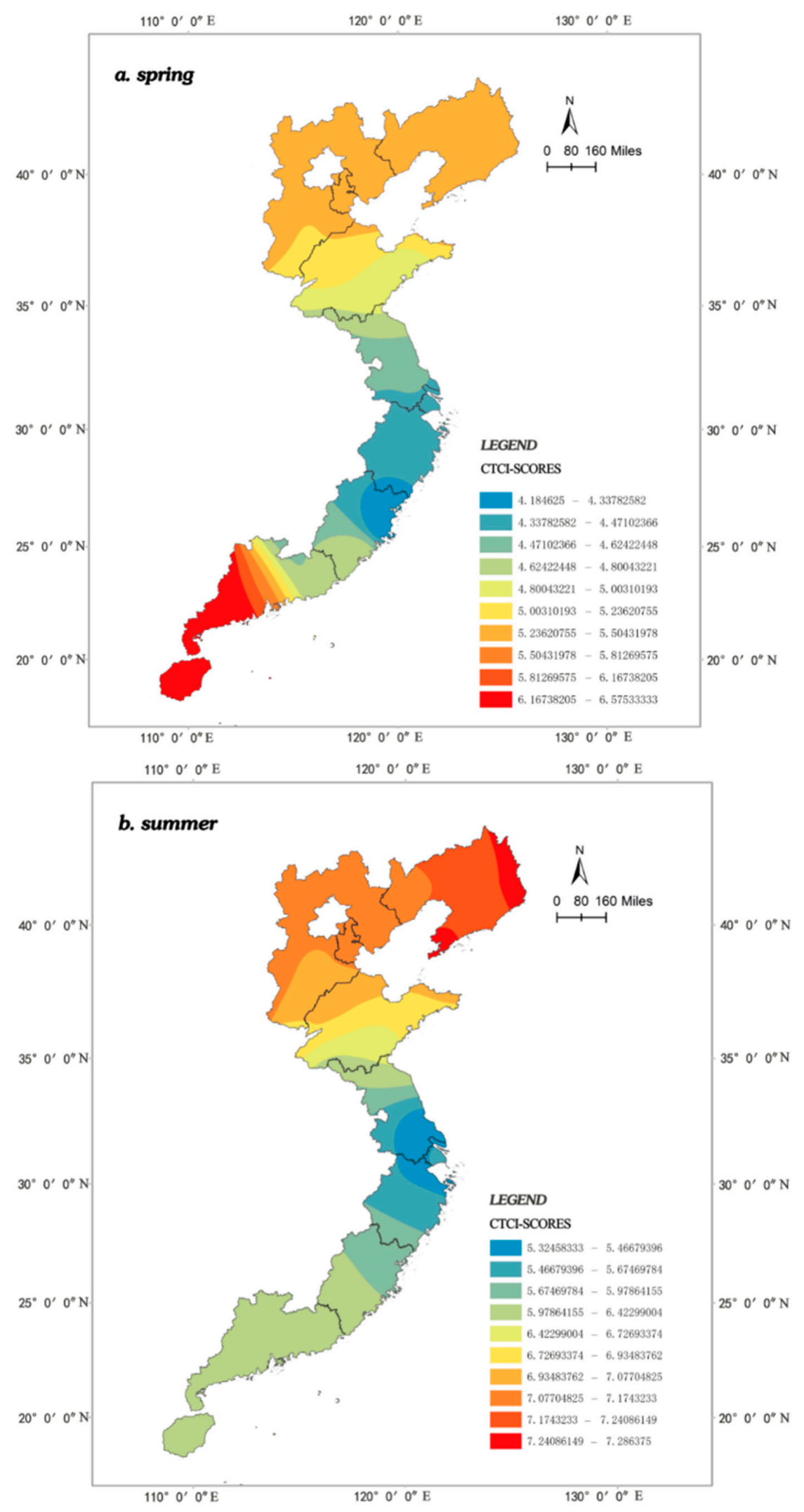

Figure 3. Cont. 

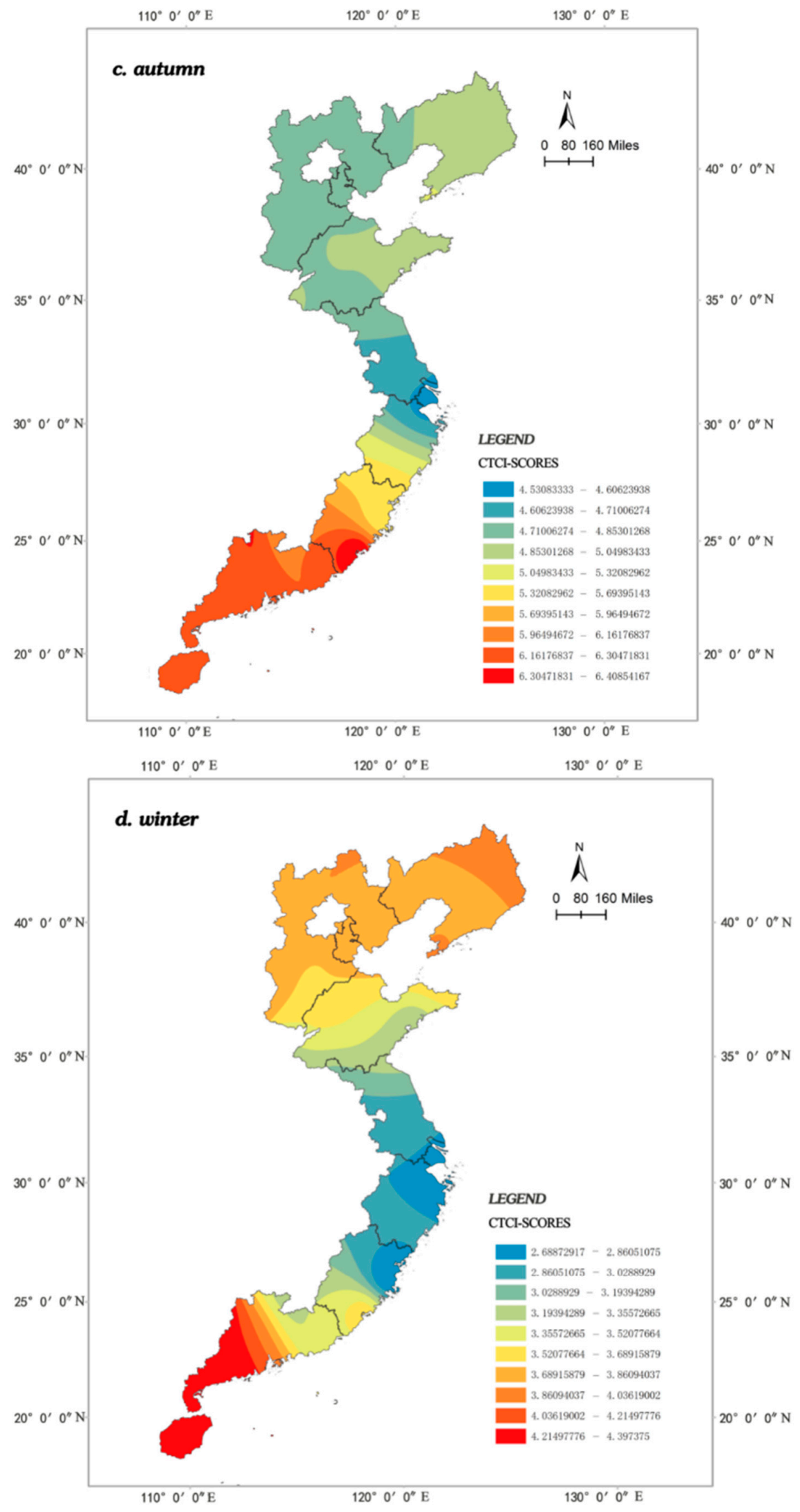

Figure 3. Spatial patterns of the seasonal average tourism climate suitability of Chinese coastal cities based on CICI scores. 
Specifically, there is an obvious difference between the CTCI and Baidu Index in July. The Baidu Index reaches its peak in most cities (7/9, Dalian, Qinhuangdao, Qingdao, Shanghai, Hangzhou, Fuzhou, Xiamen) in July. Owing to the summer vacation, the number of domestic tourists using search engines to make travel decisions reaches the highest level for the whole year. However, July is a relatively unsuitable month for coastal tourism because of the heavier precipitation and the fewer sunshine hours. Hence, the CTCI cannot reach the maximum value in July.

\subsection{Discussion}

Coastal tourism is largely regarded as one of the fastest-growing industries worldwide [2,62]. However, it is susceptible to the impacts of climate change [28,63]. Climate indices are effective tools and techniques that can translate weather and climate conditions into tourism decision-relevant information [40]. However, there are still some limitations in previous studies. First, most early studies focused on the climate conditions required by $3 S$ (sun, sea, and sand) tourism activities, but few revealed the relationship between air quality and tourism climate suitability for coastal cities facing air pollution [31]. In order to assess the tourism climate of Chinese coastal cities, we developed the CTCI, including five variables: THI, sunshine, precipitation, wind, and AQI. Encouragingly, the CTCI is more suitable than HCI: Beach based on correlations with the Baidu Index. The findings based on the CTCI reveal the spatial and temporal climate characteristics of China's coastal tourism cities, which could provide a convincing basis for policy makers and the tourism industry.

Second, the weather variable rating schemes of the TCIs were subjective, as they were based on the author's opinions $[14,23,64]$. Hence, in order to improve the objectivity of the weighting system of the variables, this study used the entropy method to determine the weightings of the sub-indices. The entropy method is an effective instrument to determine the index weight according to the variation degree of each index value. It is an objective weighting method and can avoid the bias induced by subjective influence to a certain extent [65]. The results showed that sunshine and THI were the predominant weather variables, and air quality was more critical than wind.

Third, traditional official data or micro-survey data are insufficient to describe tourist behavior at precise time and space scales [18], such as visitation numbers [40], occupancy rates [48], and questionnaires [15], because these structured data can be insufficient due to its small sample size. Recently, Baidu search data have been used widely in the forecasting of tourist arrivals and hotels in China [57,58]. Compared to the traditional validation data, big data are timely and accurate tourism indicators [66] and are free for everyone. Thus, we used the Baidu Index to validate and improve the model's accuracy. This is important to highlight because we took the initiative to try and apply big data to the development and validation of the tourism climate index. Overall, the findings show that the CTCI is more suitable for the climate assessment of Chinese coastal cities compared to the HCI: Beach. However, the peak demand is influenced by the institutional seasonality in July. Moreover, lower fitting degrees (Fuzhou and Xiamen; see Table 8) indicate that there may be other factors influencing the searching behaviors, such as attractive promotions. In the future, big data, including Google Trends, mobile phone signals, and network texts of tourists, should be fully used to accurately detect the relationship between climate and tourism development in different temperature zones.

In future development, coastal tourism cities located in the same temperature zone should implement differentiated marketing strategies to overcome the problem of the homogeneity of climate resources. China's government should adjust the holiday system through the comprehensive promotion of annual vacations with pay, because the current holiday system leads to tourism problems between supply and demand. Next, tourism enterprises should adjust and upgrade their products and services to enhance their adaptation to climate change. Travel plans with regard to coastal tourism activities should be customizable, to better meet the needs of tourists on hazy days [18]. In addition, improving the urban air quality is another effective strategy to improve the attractiveness 
and sustainability of Chinese coastal tourism cities. In fact, China implemented the Action Plan of Air Pollution Prevention and Control (APPC-AP) in 2013 as the strictest measures for multi-pollutant control [67]. In conclusion, shaping a destination image of "blue seas, blue skies, and white clouds" is crucial for the competitiveness and sustainability of these coastal tourism cities.

\section{Conclusions}

This paper focuses on the tourism climate assessment of Chinese coastal cities in the context of air pollution. The most significant contribution of this study may lie in the development of a novel Coastal Tourism Climate Index (CTCI), suitable for coastal cities facing air pollution, using big data. Most early studies focused on the tourism climate conditions required by $3 S$ (sun, sea, and sand) tourism activities, but few revealed the relationship between air quality and tourism climate suitability for coastal tourism activities taking place from cities to marine areas. In order to assess the tourism climate of Chinese coastal cities accurately, the CTCI combines five weather sub-indices: THI, sunshine, precipitation, wind, and AQI. The findings underline the importance of air quality for coastal tourism climate assessment in China. Through deepening the understanding of coastal tourism climate conditions, this study provides theoretical guidance for sustainable tourism marketing and management in Chinese coastal cities. Ideally, future research could build on the CTCI to assess the climate for tourism destinations facing serious air pollution in other geographic contexts.

Despite various implications, there are still some limitations. First, in order to ensure the consistency of the temporal granularity of the variables, the use of 96 months of data to develop and validate the index was a limitation of our study. More data should be included in future studies. Second, the ocean influences weather and climate directly. But tourist behavior is influenced by a variety of factors, such as weather, landscape, cultural backgrounds, social influences, personality, economic situations, education etc. Due to the complex relationship between climate and tourist behavior, CTCI should be modified continuously according to verification of more typical cases, to improve accuracy and universality. Third, natural disasters such as sea level rising could be considered as an essential component in tourism climate indices for coastal resorts in further research. Fourth, big data such as Google Trends, mobile phone signals, and network texts should be used to accurately detect the relationship between climate and tourism development. At the same time, more attention should be paid to the protection of personal privacy.

Author Contributions: Conceptualization, C.G. and J.L.; Methodology, C.G.; Software, C.G.; Validation, C.G.; Formal Analysis, C.G.; Investigation, J.L.; Resources, J.L.; Data Curation, C.G.; WritingOriginal Draft Preparation, C.G.; Writing—Review \& Editing, S.Z., H.Z. and X.Z.; Visualization, C.G.; Supervision, J.L.; Project Administration, J.L.; Funding Acquisition, H.Z. All authors have read and agreed to the published version of the manuscript.

Funding: This research was funded by the National Key Research and Development Program of China [grant numbers 2019YFC0507802]; the Strategic Priority Research Program of Chinese Academy of Sciences [grant number XDA23100302]; and the National Natural Science Foundation of China (NSFC) [grant number 41801139].

Institutional Review Board Statement: Not applicable.

Informed Consent Statement: Not applicable.

Data Availability Statement: Climate data (China Meteorological Data Network, http:/ / data.cma. cn/, accessed on 5 March 2021); Air Quality Index (the Ministry of Ecology and Environment of the People's Republic of China, https:/ / www.mee.gov.cn/, accessed on 8 March 2021); Baidu Index (https:/ /index.baidu.com/v2/index.html\#/, accessed on 15 March 2021).

Conflicts of Interest: The authors declare no conflict of interest. 


\section{References}

1. Ministry of Natural Resources of the People's Republic of China. Statistical Communique of China's Marine Economy of 2020. 2021. Available online: http://www.mnr.gov.cn/sj/sjfw/hy/gbgg/zghyjjtjgb/ (accessed on 19 June 2021).

2. Hall, C.M. Trends in ocean and coastal tourism: The end of the last frontier? Ocean Coast. Manag. 2001, 44, 601-618. [CrossRef]

3. Dimitrovski, D.; Lemmetyinen, A.; Nieminen, L.; Pohjola, T. Understanding coastal and marine tourism sustainability-A multi-stakeholder analysis. J. Destin. Mark. Manag. 2021, 19, 100554. [CrossRef]

4. Méndez-Lázaro, P.A.; Terrasa-Soler, J.J.; Torres-Peña, C.; Guzmán-González, P.; Rodríguez, S.; Alemán, M.; Seguinot, T. Tourism and climate conditions in San Juan, Puerto Rico, 2000-2010. Ecol. Soc. 2014, 19, 11. [CrossRef]

5. De Freitas, C.R. Recreation climate assessment. Int. J. Climatol. 1990, 10, 89-103. [CrossRef]

6. Martín, M.B.G. Weather, climate and tourism a geographical perspective. Ann. Tour. Res. 2005, 32, 571-591. [CrossRef]

7. Gössling, S.; Scott, D.; Hall, C.M.; Ceron, J.P.; Dubois, G. Consumer behaviour and demand response of tourists to climate change. Ann. Tour. Res. 2012, 39, 36-58. [CrossRef]

8. Lam-Gonzalez, Y.E.; Leon, C.J.; de Leon, J. Assessing the effects of the climatic satisfaction on nautical tourists' on-site activities and expenditure decisions. J. Destin. Mark. Manag. 2019, 14, 100372. [CrossRef]

9. Amelung, B.; Nicholls, S.; Viner, D. Implications of global climate change for tourism flows and seasonality. J. Travel Res. 2007, 45, 285-296. [CrossRef]

10. Chaabouni, S. China's regional tourism efficiency: A two-stage double bootstrap data envelopment analysis. J. Destin. Mark. Manag. 2019, 11, 183-191. [CrossRef]

11. Dubois, G.; Ceron, J.P.; Dubois, C.; Frias, M.D.; Herrera, S. Reliability and usability of tourism climate indices. Earth Perspect. 2016, 3, 2. [CrossRef]

12. Gössling, S.; Abegg, B.; Steiger, R. "It was raining all the time!": Expost tourist weather perceptions. Atmosphere 2016, 7, 10. [CrossRef]

13. Mieczkowski, Z. The Tourism Climatic Index: A Method of Evaluating World Climates for Tourism. Can. Geogr. 1985, 29, 220-233. [CrossRef]

14. Morgan, R.; Gatell, E.; Junyent, R.; Micallef, A.; Özhan, E.; Williams, A.T. An improved user-based beach climate index. J. Coast. Conserv. 2000, 6, 41-50. [CrossRef]

15. De Freitas, C.R.; Scott, D.; McBoyle, G. A second generation climate index for tourism (CIT): Specification and verification. Int. J. Biometeorol. 2008, 52, 399-407. [CrossRef]

16. Hejazizadeh, Z.; Karbalaee, A.; Hosseini, S.A.; Tabatabaei, S.A. Comparison of the holiday climate index (HCI) and the tourism climate index (TCI) in desert regions and Makran coasts of Iran. Arab. J. Geosci. 2019, 12, 803. [CrossRef]

17. Wang, L.; Fang, B.; Law, R. Effect of air quality in the place of origin on outbound tourism demand: Disposable income as a moderator. Tour. Manag. 2018, 68, 152-161. [CrossRef]

18. Wang, L.; Zhou, X.; Lu, M.; Cui, Z. Impacts of haze weather on tourist arrivals and destination preference: Analysis based on Baidu Index of 73 scenic spots in Beijing, China. J. Clean. Prod. 2020, 273, 122887. [CrossRef]

19. Deng, T.; Li, X.; Ma, M. Evaluating impact of air pollution on China's inbound tourism industry: A spatial econometric approach. Asia Pac. J. Tour. Res. 2017, 22, 771-780. [CrossRef]

20. Lin, B.; Ling, C. Heating price control and air pollution in China: Evidence from heating daily data in autumn and winter. Energy Build. 2021, 250, 111262. [CrossRef]

21. Lohmann, M.; Kaim, E. Weather and holiday destination preferences image, attitude and experience. Tour. Rev. 1999, 54, 54-64. [CrossRef]

22. Scott, D.; Gössling, S.; Hall, C.M. International tourism and climate change. Wiley Interdiscip. Rev. Clim. Chang. $2012,3,213-232$. [CrossRef]

23. Ma, S.; Craig, C.A.; Feng, S. The Camping Climate Index (CCI): The development, validation, and application of a camping-sector tourism climate index. Tour. Manag. 2020, 80, 104105. [CrossRef]

24. Rutty, M.; Scott, D. Bioclimatic comfort and the thermal perceptions and preferences of beach tourists. Int. J. Biometeorol. 2015, 59, 37-45. [CrossRef] [PubMed]

25. Steiger, R.; Scott, D.; Abegg, B.; Pons, M.; Aall, C. A critical review of climate change risk for ski tourism. Curr. Issues Tour. 2019, 22, 1343-1379. [CrossRef]

26. Hewer, M.J.; Scott, D.; Gough, W.A. Tourism climatology for camping: A case study of two Ontario parks (Canada). Theor. Appl. Climatol. 2015, 121, 401-411. [CrossRef]

27. Hewer, M.; Scott, D.; Fenech, A. Seasonal weather sensitivity, temperature thresholds, and climate change impacts for park visitation. Tour. Geogr. 2016, 18, 297-321. [CrossRef]

28. Susanto, J.; Zheng, X.; Liu, Y.; Wang, C. The impacts of climate variables and climate-related extreme events on island country's tourism: Evidence from Indonesia. J. Clean. Prod. 2020, 276, 124204. [CrossRef]

29. Prideaux, B. Resort Destinations: Evolution, Management and Development; Taylor \& Francis: London, UK, 2009. [CrossRef]

30. Losada, I.; Toimil, A.; Munoz, A.; Garcia-Fletcher, A.P.; Diaz-Simal, P. A planning strategy for the adaptation of coastal areas to climate change: The Spanish case. Ocean Coast. Manag. 2019, 182, 104983. [CrossRef]

31. Semazzi, F. Air quality research: Perspective from climate change modelling research. Environ. Int. 2003, 29, 253-261. [CrossRef] 
32. Mostafanezhad, M. The materiality of air pollution: Urban political ecologies of tourism in Thailand. Tour. Geogr. 2020, 4, 855-872. [CrossRef]

33. Zhang, N.; Ren, R.; Zhang, Q. Air pollution and tourism development: An interplay. Ann. Tour. Res. 2020, 85, 103032. [CrossRef]

34. Dong, D.; Xu, X.; Yu, H.; Zhao, Y. The Impact of Air Pollution on Domestic Tourism in China: A Spatial Econometric Analysis. Sustainability 2019, 11, 4148. [CrossRef]

35. Robaina, M.; Madaleno, M.; Silva, S.; Eusebio, C.; Carneiro, M.J.; Gama, C.; Oliveira, K.; Russo, M.A.; Monteiro, A. The relationship between tourism and air quality in five European countries. Econ. Anal. Policy 2020, 67, 261-272. [CrossRef]

36. Xu, B.; Dong, D. Evaluating the Impact of Air Pollution on China's Inbound Tourism: A Gravity Model Approach. Sustainability 2020, 12, 1456. [CrossRef]

37. Zhou, X.; Jimenez, Y.; Rodriguez, J.; Hernandez, J. Air pollution and tourism demand: A case study of Beijing, China. Int. J. Tour. Res. 2019, 21, 747-757. [CrossRef]

38. Matos-Wasem, R. The good alpine air in the tourism of today and tomorrow: Symbolic capital to enhance and preserve. Rev. De Géogr. Alp. 2005, 93, 105-113. [CrossRef]

39. Yu, G.; Schwartz, Z.; Walsh, J.E. A weather-resolving index for assessing the impact of climate change on tourism related climate resources. Clim. Chang. 2009, 95, 551-573. [CrossRef]

40. Matthews, L.; Scott, D.; Andrey, J. Development of a data-driven weather index for beach parks tourism. Int. J. Biometeorol. 2019, 65, 749-762. [CrossRef]

41. Rutty, M.; Scott, D.; Matthews, L.; Burrowes, R.; Trotman, A.; Mahon, R.; Charles, A. An Inter (HCI: Beach) and the tourism climate index (TCI) to explain canadian tourism arrivals to the Caribbean. Atmosphere 2020, 11, 412. [CrossRef]

42. Moreno, A.; Amelung, B. Climate Change and Tourist Comfort on Europe's Beaches in Summer: A Reassessment. Coast. Manag. 2009, 37, 550-568. [CrossRef]

43. Yu, D.D.; Rutty, M.; Scott, D.; Li, S. A comparison of the holiday climate index: Beach and the tourism climate index across coastal destinations in China. Int. J. Biometeorol. 2021, 65, 741-748. [CrossRef] [PubMed]

44. Demiroglu, O.C.; Saygili-Araci, F.S.; Pacal, A.; Hall, C.M.; Kurnaz, M.L. Future Holiday Climate Index (HCI) performance of urban and beach destinations in the Mediterranean. Atmosphere 2020, 11, 911. [CrossRef]

45. Bigano, A.; Hamilton, J.M.; Tol, R.S.J. The impact of climate on holiday destination choice. Clim. Chang. 2006, 76, 389-406. [CrossRef]

46. Moreno, A. Mediterranean Tourism and Climate (Change): A Survey-Based Study. Tour. Hosp. Plan. Dev. 2010, 7, 253-265. [CrossRef]

47. Scott, D.; Gossling, S.; De Freitas, C.R. Preferred climates for tourism: Case studies from Canada, New Zealand and Sweden. Clim. Res. 2008, 38, 61-73. [CrossRef]

48. Scott, D.; Rutty, M.; Amelung, B.; Tang, M. An inter-comparison of the Holiday Climate Index (HCI) and the Tourism Climate Index (TCI) in Europe. Atmosphere 2016, 7, 80. [CrossRef]

49. Li, X.; Law, R.; Xie, G.; Wang, S. Review of tourism forecasting research with internet data. Tour. Manag. 2021, 83, 104245. [CrossRef]

50. Li, X.; Pan, B.; Law, R.; Huang, X. Forecasting tourism demand with composite search index. Tour. Manag. 2017, 59, 57-66. [CrossRef]

51. Choi, H.; Varian, H. Predicting the Present with Google Trends. Econ. Rec. 2012, 88, 2-9. [CrossRef]

52. Pan, B.; Wu, D.C.; Song, H. Forecasting hotel room demand using search engine data. J. Hosp. Tour. Technol. 2012, 3, 196-210. [CrossRef]

53. Bangwayo-Skeete, P.F.; Skeete, R.W. Can Google data improve the forecasting performance of tourist arrivals? Mixed-data sampling approach. Tour. Manag. 2015, 46, 454-464. [CrossRef]

54. Bokelmann, B.; Lessmann, S. Spurious patterns in Google Trends data-An analysis of the effects on tourism demand forecasting in Germany. Tour. Manag. 2019, 75, 1-12. [CrossRef]

55. Lv, S.; Peng, L.; Wang, L. Stacked autoencoder with echo-state regression for tourism demand forecasting using search query data. Appl. Soft Comput. 2018, 73, 119-133. [CrossRef]

56. Peng, G.; Liu, Y.; Wang, J.; Gu, J. Analysis of the prediction capability of web search data based on the HE-TDC method-Prediction of the volume of daily tourism visitors. J. Syst. Sci. Syst. Eng. 2017, 26, 163-182. [CrossRef]

57. Huang, X.; Zhang, L.; Ding, Y. The Baidu Index: Uses in predicting tourism flows-A case study of the Forbidden City. Tour. Manag. 2017, 58, 301-306. [CrossRef]

58. Zhang, B.; Pu, Y.; Wang, Y.; Li, J. Forecasting Hotel Accommodation Demand Based on LSTM Model Incorporating Internet Search Index. Sustainability 2019, 11, 4708. [CrossRef]

59. Geng, Y.; Wei, Z.; Zhang, H.; Maimaituerxun, M. Analysis and Prediction of the Coupling Coordination Relationship between Tourism and Air Environment: Yangtze River Economic Zone in China as Example. Discret. Dyn. Nat. Soc. 2020, $2020,1406978$. [CrossRef]

60. Zhang, H.; Gu, C.; Gu, L.; Zhang, Y. The evaluation of tourism destination competitiveness by TOPSIS \& information entropy-A case in the Yangtze River Delta of China. Tour. Manag. 2011, 32, 443-451. [CrossRef]

61. Fan, Y.; Guo, L. The Climate Suitability of Tourism at the Coastline Destination of China. J. Nat. Resour. 1998, 4, 17-24. (In Chinese) 
62. Jia, Z. Modeling and Analyzing the Dynamic Factors of Economic Growth Evolution in Coastal Tourism Cities. J. Coast. Res. 2020, 103, 1079-1083. [CrossRef]

63. Wilkins, E.; de Urioste-Stone, S.; Weiskittel, A.; Gabe, T. Weather sensitivity and climate change perceptions of tourists: A segmentation analysis. Tour. Geogr. 2018, 20, 273-289. [CrossRef]

64. De Freitas, C.R. Tourism climatology: Evaluating environmental information for decision making and business planning in the recreation and tourism sector. Int. J. Biometeorol. 2003, 48, 45-54. [CrossRef] [PubMed]

65. Wang, X.; Liu, D. The coupling coordination relationship between tourism competitiveness and economic growth of developing countries. Sustainability 2020, 12, 2350. [CrossRef]

66. Volo, S. Tourism statistics, indicators and big data: A perspective article. Tour. Rev. 2019, 75, 304-309. [CrossRef]

67. Ma, Z.; Liu, R.; Liu, Y.; Bi, J. Effects of air pollution control policies on PM2.5 pollution improvement in China from 2005 to 2017: A satellite-based perspective. Atmos. Chem. Phys. 2019, 19, 6861-6877. [CrossRef] 